\title{
KEEFEKTIFAN MODUL KOMIK TEMATIK BERBASIS MULTIPLE INTELEGENCE (MI) UNTUK SISWA KELAS V SD
}

\author{
Arnelia Dwi Yasa ${ }^{1}$, Denna Delawanti Chrisyarani ${ }^{2}$, Sa'dun Akbar $^{3}$, Alif Mudiono ${ }^{4}$ \\ 1,2 Pendidikan Guru Sekolah Dasar, Universitas Kanjuruhan Malang \\ ${ }^{3,4}$ Pendidikan Guru Sekolah Dasar, Universitas Negeri Malang \\ Email:arnelia@unikama.ac.id
}

\begin{abstract}
The MI-based thematic comic module has the advantage of integrative thematic learning combined with MI. Modules are developed to know and develop students' intelligence. MI theory that is applied in thematic learning, can be used to activate intelligence that has not been seen in students. Development of MI-based modules is rarely found in the field. Modules used in schools, emphasizing cognitive aspects. The purpose of this study was to determine the effectiveness of MI-based thematic comic modules. Effectiveness data is obtained from the average of all tests given to students after using the module. Data analysis for assessment in the form of tests. The effectiveness of the modules tested in seven schools showed the acquisition of scores with an average of 76.75 students' effectiveness, students reached a score of $\geq 75$. The percentage of module completeness $74 \%$ can be said that the Thematic Comic Module Based on Class V SD MI is effective for use in learning. The results showed that MI-based thematic comic modules were effective.
\end{abstract}

\section{Keyword: Effectiveness, Comics, Thematic, Multiple Intelligence}

\begin{abstract}
Abstrak: Modul komik tematik berbasis MI memiliki kelebihan berupa pembelajaran tematik integratif yang dipadukan dengan MI. Modul dikembangkan untuk mengetahui dan mengembangkan kecerdasan siswa. Teori MI yang diterapkan dalam pembelajaran tematik, dapat digunakan untuk mengaktifkan kecerdasan yang belum terlihat pada diri siswa. Pengembangan modul berbasis MI jarang ditemukan dilapangan. Modul yang digunakan di sekolah, menekankan pada aspek kognitif. Tujuan penelitian ini adalah untuk mengetahui keefektifan modul komik tematik berbasis MI. Data keefektifan diperoleh dari rata-rata seluruh tes yang diberikan kepada siswa setelah menggunakan modul. Analisis data untuk penilaian berupa tes. Hasil kefektifan modul yang diujicobakan pada tujuh sekolah menunjukkan perolehan nilai dengan rata-rata keefektifan siswa sebesar 76,75 , siswa mencapai mencapai skor $\geq 75$. Prosentase ketuntasan modul $74 \%$ dapat dikatakan bahwa Modul Komik Tematik Berbasis MI Kelas V SD efektif untuk digunakan dalam pembelajaran. Hasil penelitian menunjukkan bahwa modul komik tematik berbasis MI efektif.
\end{abstract}

Kata Kunci: Keefektifan, Komik, Tematik, Multiple Intelegence

\section{PENDAHULUAN}

Pembelajaran tematik dimaknai sebagai pembelajaran yang dirancang berdasarkan tema-tema tertentu. Istilah pembelajaran tematik pada dasarnya adalah model pembelajaran terpadu yang menggunakan tema untuk mengaitkan beberapa mata pelajaran sehingga dapat memberikan pengalaman bermakna kepada siswa (Depdiknas, 2006). Trianto (2010) menyatakan bahwa pembelajaran terpadu sebagai suatu konsep yang menggunakan pendekatan pembelajaran yang melibatkan konsep-konsep secara terkoneksi baik secara inter maupun antar mata pelajaran. Pembelajaran tematik merupakan model integrasi antar mata pelajaran. Pembelajaran tematik menekankan keaktifan siswa dalam pembelajaran baik secara fisik, mental, intelektual maupun emosional guna tercapainya hasil belajar yang optimal.

Komik merupakan salah satu media dua dimensi dengan jenis media grafis. Menurut Sudjana dan Rivai (2010) komik merupakan media yang dapat mengkomunikasikan fakta-fakta dan gagasan-gagasan secara jelas, kuat 
melalui perpaduan antara penggunaan kata-kata dan gambar.

Setiap siswa memiliki intelegence yang berbeda-beda. Perbedaan intelegence yang dimiliki oleh siswa dilatarbelakangi oleh pengalaman siswa dalam kehidupan sehari-hari dan faktor genetik. Intelijen adalah kemampuan untuk memecahkan masalah atau menciptakan produk berharga dalam satu atau beberapa lingkungan, budaya, dan masyarakat (Gardner, 2003).

Strategi pembelajaran, modul yang digunakan di sekolah penting dikembangkan sesuai dengan teori MI, karena jenis kecerdasan setiap siswa berbeda (Onika, 2008). Gardner (2003) menjelaskan bahwa ada delapan kecerdasan dalam teori MI. Delapan kecerdasan itu meliputi kecerdasan linguistik (linguistic intelligence), kecerdasan logis-matematis (logicalmathematical intelligences), kecerdasan musikal (musical intelligence), kecerdasan spasial (spatial intelligence), kecerdasan kinestetik-tubuh (bodilykinesthetic intelligence), kecerdasan interpersonal (interpersonal intelligence), kecerdasan intrapersonal (intrapersonal intelligence), dan kecerdasan naturalis (naturalist intelligence).

Penerapan pembelajaran

berorientasi MI mendukung pelaksanaan pembelajaran tematik. Modul komik tematik yang dikembangkan sesuai teori MI dapat mengukur kecerdasan yang dimiliki oleh siswa. Chatib (2009) menyatakan bahwa penggunaan pembelajaran dengan sistem MI mampu meningkatkan hasil belajar, minat siswa dalam pembelajaran. Komik sebagai media pembelajaran merupakan alat yang berfungsi untuk menyampaikan pesan pembelajaran kepada siswa. Pembelajaran akan berjalan dengan maksimal jika pesan/materi disampaikan secara jelas, runtut, dan menarik. Komik dikembangkan sesuai dengan tema dan karakteristik siswa kelas V SD.
Komik dalam modul ini menceritakan kehidupan sehari-hari siswa, menanamkan sikap dan moral yang baik pada siswa. Sehingga, siswa akan tertarik untuk mempelajarinya. Hal tersebut sesuai dengan pernyataan Mardiningsih (2009) penggunaan media komik apabila disajikan dengan baik akan merangsang minat dan perhatian siswa, karena sifatnya yang dapat membuat rasa senang hal ini berdampak pada peningkatan hasil.

Pemilihan media komik didasarkan pada suatu alasan bahwa tujuan mengajar di kelas bukan hanya mentransformasikan pengetahuan saja, tetapi menumbuhkan peran aktif siswa. Komik tidak hanya dapat tercipta sebagai hiburan, namun komik juga dapat menjadi sebuah media dalam pembelajaran dengan menyatukan materi atau bahan ajar ke dalam bentuk gambar.

Penelitian pengembangan komik pernah dilakukan oleh beberapa peneliti. Peneliti sebelumnya telah melakukan penelitian tentang Pengembangan Media Komik Pembelajaran Matematika Meningkatkan Motivasi dan Prestasi Belajar Siswa Kelas V. Hasil menunjukkan bahwa media komik pembelajaran matematika yang digunakan dapat meningkatkan motivasi belajar siswa sebesar 0,65 tergolong dalam kategori sedang menurut skala gain, sedangkan prestasi belajar siswa sebesar 0,73 tergolong dalam kategori tinggi menurut skala gain. Pengembangan Media Komik Bergambar Materi Sistem Saraf Untuk Pembelajaran Yang Menggunakan Strategi PQ4R (Wahyuningsih, 2011). Hasilnya menunjukkan bahwa modul menarik, praktis dan efektif. Tujuan penelitian ini adalah untuk mengetahui keefektifan modul komik tematik berbasis MI.

\section{METODE}

Data keefektifan diperoleh dari rata-rata seluruh tes yang diberikan 
kepada siswa setelah menggunakan modul dan lembar pengamatan proses. Analisis data untuk penilaian berupa tes. Setelah melakukan analisis deskriptif, peneliti mencari skor rata-rata keseluruhan hasil belajar siswa. Untuk mengolah data keefektifan dari tes yang diberikan kepada siswa dan pengamatan proses siswa, digunakan rumus yang diadaptasi dari Arikunto (2012:299).

Keterangan:

$$
\bar{X}=\frac{\sum x}{\sum N}
$$

$$
\begin{array}{ll}
\underset{\bar{X}}{\Sigma x} & =\text { Skor rata-rata } \\
\sum N & =\text { Jumlah keseluruhan skor siswa } \\
\sum N & =\text { Jumlah siswa }
\end{array}
$$

Modul dikatakan efektif dilihat dari hasil belajar dan hasil pengamatan proses siswa jika rata-rata hasil belajar siswa mencapai $\geq 75(\mathrm{KKM})$. Jika rata- rata hasil belajar siswa kurang dari 75, maka modul dikatakan kurang efektif.

Tabel 1. Kriteria Kefektifan Modul Komik Tematik berbasis MI

\begin{tabular}{lcl}
\hline $\mathbf{N}$ & Skor Keefektifan & \multicolumn{1}{c}{ Tingkat Validitas } \\
\hline 1. & $85-100$ & Sangat efektif, tidak perlu revisi \\
\hline 2. & $70-84$ & Efektif, tidak perlu revisi \\
\hline 3. & $50-69$ & Kurang efektif, perlu revisi \\
\hline 5. & $0-49$ & Tidak efektif, revisi total \\
\hline
\end{tabular}

(sumber: Yamasari, 2010:12)

\section{HASIL DAN PEMBAHASAN}

Data keefektifan diperoleh dari hasil belajar siswa. Hasil belajar adalah data yang berasal dari hasil pengerjaan latihan, tugas, tes mandiri pada tiap penggalan dan tes akhir modul yang terdapat dalam modul siswa. Data hasil belajar diambil dari tujuh sekolah (SDN Sukun 1 Malang, SDN Bandungrejosari 3, SDN Lesanpuro 3, SDN Kedungkandang 1, SD Laboraturium UM, SDN Purwodadi, SDN kesatrian 2) Hasil belajar siswa pada aspek pengetahuan dapat dilihat pada tabel 4

\begin{tabular}{|c|c|c|c|c|}
\hline $\begin{array}{l}\text { Rentan } \\
\text { g Nilai }\end{array}$ & $\begin{array}{c}\text { Frekuen } \\
\text { si }\end{array}$ & $\begin{array}{c}\text { Prosenta } \\
\text { se }\end{array}$ & $\begin{array}{c}\text { Tunt } \\
\text { as }\end{array}$ & $\begin{array}{c}\text { Tidak } \\
\text { Tunta } \\
\text { S }\end{array}$ \\
\hline $95-100$ & 1 & $2,5 \%$ & 1 & - \\
\hline $85-94$ & 20 & $50 \%$ & 20 & - \\
\hline $75-84$ & 14 & $35 \%$ & 14 & - \\
\hline $65-74$ & 1 & $2,5 \%$ & - & 1 \\
\hline $56-64$ & 0 & $0 \%$ & - & 0 \\
\hline $46-55$ & 3 & $7,5 \%$ & - & 3 \\
\hline $36-45$ & 1 & $2,5 \%$ & - & 1 \\
\hline Jumlah & 40 & 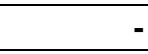 & 35 & 5 \\
\hline $\begin{array}{c}\text { Prosenta } \\
\text { se } \\
\end{array}$ & - & $100 \%$ & $87,5 \%$ & $\begin{array}{c}12,5 \\
\%\end{array}$ \\
\hline
\end{tabular}
berikut ini.
Tabel 2 Distribusi Frekuensi Data Hasil Belajar Siswa SDN Sukun 1 Malang

Berdasarkan table 2 dapat diketahui bahwa hasil belajar siswa $\mathrm{V}$ dalam mempelajari modul sebanyak 1 siswa $(2,5 \%)$ berada pada rentang 36-45, sebanyak 3 siswa $(7,5 \%)$ berada pada rentang 46-55, sebanyak 1 siswa $(2,5 \%)$ berada pada rentang 65-74, sebanyak 14 siswa $(35 \%)$ berada pada rentang 75-84, sebanyak 20 siswa $(50 \%)$ berada pada rentang 85-94, dan sebanyak 1 siswa (2,5\%) berada pada rentang 95-100. Siswa yang tuntas berjumlah 35 dengan persentase $87,5 \%$. Sedangkan yang tidak tuntas berjumlah 5 siswa dengan persentase $12,5 \%$. Hasil belajar pada SD Laboraturium dapat dilihat pada Tabel 3.

Tabel 3 Distribusi Frekuensi Data Hasil Belajar Siswa SD Laboratorium UM

\begin{tabular}{ccccc}
\hline $\begin{array}{c}\text { Rentan } \\
\text { g Nilai }\end{array}$ & $\begin{array}{c}\text { Frekuen } \\
\text { si }\end{array}$ & $\begin{array}{c}\text { Prosenta } \\
\text { se }\end{array}$ & $\begin{array}{c}\text { Tunta } \\
\text { s }\end{array}$ & $\begin{array}{c}\text { Tidak } \\
\text { Tunta } \\
\text { s }\end{array}$ \\
\hline $92-100$ & 4 & $11,8 \%$ & 4 & - \\
\hline $83-91$ & 13 & $38,2 \%$ & 13 & - \\
\hline $74-82$ & 9 & $26,5 \%$ & 9 & - \\
\hline $65-73$ & 3 & $8,9 \%$ & - & 3 \\
\hline $56-64$ & 2 & $5,9 \%$ & - & 2 \\
\hline $47-55$ & 1 & $2,9 \%$ & - & 1 \\
\hline $38-46$ & 2 & $5,9 \%$ & - & 2 \\
\hline Jumlah & $\mathbf{3 4}$ & & $\mathbf{2 6}$ & $\mathbf{8}$ \\
\hline $\begin{array}{c}\text { Prosenta } \\
\text { se }\end{array}$ & - & $\mathbf{1 0 0 \%}$ & $\mathbf{7 6 , 5 \%}$ & $\mathbf{2 3 , 5}$ \\
\hline \multicolumn{7}{c}{ Berdasarkan tabel 3 dapat diketahui }
\end{tabular}

bahwa hasil belajar siswa $\mathrm{V}$ dalam mempelajari modul sebanyak 2 siswa $(5,9 \%)$ berada pada rentang 38-46, sebanyak 1 siswa $(2,9 \%)$ berada pada rentang 56-64, sebanyak 3 siswa $(8,9 \%)$ berada pada rentang 65-73, sebanyak 9 
siswa $(26,5 \%)$ berada pada rentang $74-$ 82 , sebanyak 13 siswa $(38,2 \%)$ berada pada rentang 83-91, dan sebanyak 4 siswa $(11,8 \%)$ berada pada rentang 92100. Siswa yang tuntas berjumlah 26 dengan persentase $76,5 \%$. Sedangkan yang tidak tuntas berjumlah 8 siswa dengan persentase $23,5 \%$. Hasil belajar pada SD Kesatrian 2 dapat dilihat pada Tabel 4.

Tabel 4 Distribusi Frekuensi Data Hasil Belajar Siswa SDN Kesatrian 2

\begin{tabular}{|c|c|c|c|c|}
\hline $\begin{array}{c}\text { Rentang } \\
\text { Nilai }\end{array}$ & $\begin{array}{c}\text { Frekuens } \\
\text { i }\end{array}$ & $\begin{array}{c}\text { Prosentas } \\
\text { e }\end{array}$ & $\begin{array}{c}\text { Tunta } \\
\text { s }\end{array}$ & $\begin{array}{c}\text { Tidak } \\
\text { Tunta } \\
\text { s } \\
\end{array}$ \\
\hline $89-100$ & 2 & $6,7 \%$ & 2 & - \\
\hline $79-88$ & 15 & $50 \%$ & 15 & - \\
\hline $69-78$ & 8 & $26,7 \%$ & 5 & 3 \\
\hline $59-68$ & 1 & $3,3 \%$ & - & 1 \\
\hline $49-58$ & 1 & $3,3 \%$ & - & 1 \\
\hline $39-48$ & 2 & $6,7 \%$ & - & 2 \\
\hline $28-38$ & 1 & $3,3 \%$ & - & 1 \\
\hline Jumlah & 30 & - & 22 & 8 \\
\hline $\begin{array}{c}\text { Prosentas } \\
\text { e }\end{array}$ & & $100 \%$ & 73,3 & 26,7 \\
\hline
\end{tabular}

Berdasarkan tabel 4 dapat diketahui bahwa hasil belajar siswa $\mathrm{V}$ dalam mempelajari modul sebanyak 1 siswa $(3,3 \%)$ berada pada rentang 28-38, sebanyak 2 siswa $(6,7 \%)$ berada pada rentang 39-48, sebanyak 1 siswa $(3,3 \%)$ berada pada rentang 49-58, sebanyak 1 siswa $(3,3 \%)$ berada pada rentang 59-68, sebanyak 8 siswa $(26,7 \%)$ berada pada rentang 69-78, dan sebanyak 15 siswa $(50 \%)$ berada pada rentang $78-88$, sebanyak 2 siswa $(6,7 \%)$ berada pada rentang 89-100. Siswa yang tuntas berjumlah 22 dengan persentase 73,3\%. Sedangkan yang tidak tuntas berjumlah 8 siswa dengan persentase 26,7\%. Hasil belajar pada SDN Purwodadi 1 dapat dilihat pada Tabel 5.

Tabel 5 Distribusi Frekuensi Data Hasil Belajar Siswa SDN Purwodadi 1

\begin{tabular}{ccccc}
\hline $\begin{array}{c}\text { Rentan } \\
\text { g Nilai }\end{array}$ & $\begin{array}{c}\text { Frekuen } \\
\text { si }\end{array}$ & $\begin{array}{c}\text { Prosenta } \\
\text { se }\end{array}$ & $\begin{array}{c}\text { Tunta } \\
\text { s }\end{array}$ & $\begin{array}{c}\text { Tidak } \\
\text { Tunta } \\
\text { s }\end{array}$ \\
\hline $95-100$ & 0 & $0 \%$ & 0 & - \\
\hline $88-94$ & 7 & $18,4 \%$ & 7 & - \\
\hline $81-87$ & 16 & $42,1 \%$ & 16 & - \\
\hline $74-80$ & 11 & $28,9 \%$ & 10 & 1 \\
\hline $67-73$ & 1 & $2,6 \%$ & - & 1 \\
\hline
\end{tabular}

\begin{tabular}{|c|c|c|c|c|}
\hline $60-66$ & 1 & $2,6 \%$ & - & 1 \\
\hline $53-59$ & 2 & $5,3 \%$ & - & 2 \\
\hline Jumlah & 38 & - & 33 & 5 \\
\hline $\begin{array}{c}\text { Prosenta } \\
\text { se }\end{array}$ & & $100 \%$ & $86,8 \%$ & $\begin{array}{c}13,2 \\
\%\end{array}$ \\
\hline
\end{tabular}

Berdasarkan table 5 dapat diketahui bahwa hasil belajar siswa $\mathrm{V}$ dalam mempelajari modul sebanyak 2 siswa $(5,3 \%)$ berada pada rentang 53-59, sebanyak 1 siswa $(2,6 \%)$ berada pada rentang 60-66, sebanyak 1 siswa $(2,6 \%)$ berada pada rentang 67-73, sebanyak 11 siswa $(28,9 \%)$ berada pada rentang 74 80 , sebanyak 16 siswa $(42,1 \%)$ berada pada rentang 81-87, dan sebanyak 7 siswa $(18,4 \%)$ berada pada rentang 88 94. Siswa yang tuntas berjumlah 33 dengan persentase $86,8 \%$. Sedangkan yang tidak tuntas berjumlah 5 siswa dengan persentase 13,2\%. Hasil belajar pada SDN Kedung Kandang 1 dapat dilihat pada Tabel 6 .

Tabel 6 Distribusi Frekuensi Data Hasil Belajar Siswa SDN Kedungkandang 1

\begin{tabular}{ccccc}
\hline $\begin{array}{c}\text { Rentang } \\
\text { Nilai }\end{array}$ & $\begin{array}{c}\text { Frekuens } \\
\text { i }\end{array}$ & $\begin{array}{c}\text { Prosentas } \\
\mathbf{e}\end{array}$ & $\begin{array}{c}\text { Tunta } \\
\text { s }\end{array}$ & $\begin{array}{c}\text { Tidak } \\
\text { Tunta } \\
\text { s }\end{array}$ \\
\hline $93-100$ & 4 & $12,5 \%$ & 4 & - \\
\hline $86-92$ & 9 & $28,1 \%$ & 9 & - \\
\hline $79-85$ & 12 & $37,5 \%$ & 12 & - \\
\hline $72-78$ & 3 & $9,4 \%$ & 3 & - \\
\hline $65-71$ & 0 & $0 \%$ & - & 0 \\
\hline $58-64$ & 2 & $6,3 \%$ & - & 2 \\
\hline $50-57$ & 2 & $6,3 \%$ & - & 2 \\
\hline Jumlah & $\mathbf{3 2}$ & - & $\mathbf{2 8}$ & $\mathbf{4}$ \\
\hline Prosentas & & $\mathbf{1 0 0 \%}$ & $\mathbf{8 7 , 5 \%}$ & $\mathbf{1 2 , 5 \%}$ \\
e & & & & \\
\hline
\end{tabular}

Berdasarkan table 6 dapat diketahui bahwa hasil belajar siswa $\mathrm{V}$ dalam mempelajari modul sebanyak 2 siswa $(6,3 \%)$ berada pada rentang 50-57, sebanyak 2 siswa $(6,3 \%)$ berada pada rentang 58-64, sebanyak 3 siswa $(9,4 \%)$ berada pada rentang 72-78, sebanyak 12 siswa $(37,5 \%)$ berada pada rentang 79 85 , sebanyak 9 siswa $(28,1 \%)$ berada pada rentang 86-92, dan sebanyak 4 siswa $(12,5 \%)$ berada pada rentang 93100. Siswa yang tuntas berjumlah 28 dengan persentase $87,5 \%$. Sedangkan yang tidak tuntas berjumlah 4 siswa dengan persentase 12,5\% Hasil belajar 
pada SDN Bandungrejosari 3 dapat dilihat pada Tabel 7.

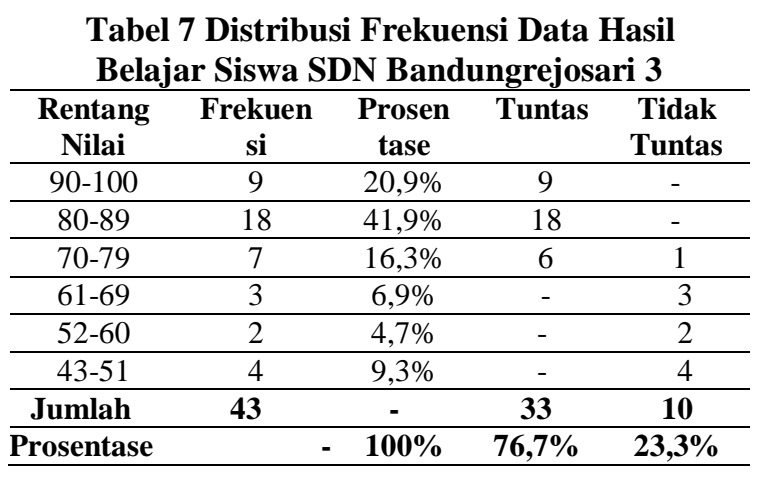

Berdasarkan table 7 dapat diketahui bahwa hasil belajar siswa $\mathrm{V}$ dalam mempelajari modul sebanyak 4 siswa $(9,3 \%)$ berada pada rentang 43-51, sebanyak 2 siswa $(4,7 \%)$ berada pada rentang 52-60, sebanyak 3 siswa $(6,9 \%)$ berada pada rentang 61-69, sebanyak 7 siswa $(16,3 \%)$ berada pada rentang 70 79 , sebanyak 18 siswa $(41,9 \%)$ berada pada rentang 80-89, dan sebanyak 9 siswa $(20,9 \%)$ berada pada rentang 90 100. Siswa yang tuntas berjumlah 33 dengan persentase $76,7 \%$. Sedangkan yang tidak tuntas berjumlah 10 siswa dengan persentase 23,3\% Hasil belajar pada SDN Lesanpuro 3 dapat dilihat pada Tabel 8.

\section{Tabel 8 Distribusi Frekuensi Data Hasil} Belajar Siswa SDN Lesanpuro 3

\begin{tabular}{ccccc}
\hline $\begin{array}{c}\text { Rentang } \\
\text { Nilai }\end{array}$ & $\begin{array}{c}\text { Frekuens } \\
\text { i }\end{array}$ & $\begin{array}{c}\text { Prosentas } \\
\mathbf{e}\end{array}$ & $\begin{array}{c}\text { Tunta } \\
\mathbf{s}\end{array}$ & $\begin{array}{c}\text { Tidak } \\
\text { Tunta } \\
\text { s }\end{array}$ \\
\hline $90-100$ & 1 & $3 \%$ & 1 & - \\
\hline $80-89$ & 5 & $15,1 \%$ & 5 & - \\
\hline $70-79$ & 4 & $12,1 \%$ & 2 & 2 \\
\hline $60-69$ & 6 & $18,2 \%$ & - & 6 \\
\hline $50-59$ & 7 & $21,2 \%$ & - & 7 \\
\hline $40-49$ & 10 & $30,3 \%$ & - & 10 \\
\hline Jumlah & $\mathbf{3 3}$ & $\mathbf{1 0 0}$ & $\mathbf{8}$ & $\mathbf{2 5}$ \\
\hline $\begin{array}{c}\text { Prosentas } \\
\text { e }\end{array}$ & - & $\mathbf{1 0 0 \%}$ & $\mathbf{2 4 , 2 \%}$ & $\mathbf{7 5 , 8 \%}$ \\
\hline
\end{tabular}

Berdasarkan tabel 8 dapat diketahui bahwa hasil belajar siswa $\mathrm{V}$ dalam mempelajari modul sebanyak 10 siswa $(30,3 \%)$ berada pada rentang 40-49, sebanyak 7 siswa $(21,2 \%)$ berada pada rentang 50-59, sebanyak 6 siswa $(18,2 \%)$ berada pada rentang 60-69, sebanyak 4 siswa $(12,1 \%)$ berada pada rentang 70 -
79, sebanyak 5 siswa $(15,1 \%)$ berada pada rentang 80-89, dan sebanyak 1 siswa (3\%) berada pada rentang 90-100. Siswa yang tuntas berjumlah 33 dengan persentase $75,8 \%$. Sedangkan yang tidak tuntas berjumlah 10 siswa dengan persentase $24,2 \%$.

Tabel 9 Deskriptif Statistik Data Hasil Belajar Siswa Mempelajari Modul

\begin{tabular}{lcccc}
\hline Nama Sekolah & $\begin{array}{c}\text { Frekue } \\
\text { nsi }\end{array}$ & $\begin{array}{c}\text { Rata- } \\
\text { Rata } \\
\text { Skor } \\
\text { Keefektif } \\
\text { an }\end{array}$ & Tuntas & $\begin{array}{c}\text { Tidak } \\
\text { Tuntas }\end{array}$ \\
\hline SDN Sukun 1 Malang & 40 & 81 & 35 & 5 \\
\hline SDN Laboratorium UM & 34 & 78,1 & 26 & 8 \\
\hline SDN Kesatrian 2 & 30 & 75,3 & 22 & 8 \\
\hline SDN Purwodadi 1 & 38 & 81 & 33 & 5 \\
\hline SDN Kedungkandang 1 & 32 & 81,6 & 28 & 4 \\
\hline SDN Bandungrejkrasi 3 & 43 & 78,6 & 33 & 10 \\
\hline SDN Lesanpuro 3 & 33 & 61,7 & 8 & 25 \\
\hline Jumlah & $\mathbf{2 5 0}$ & - & $\mathbf{1 8 5}$ & $\mathbf{6 5}$ \\
\hline Rata-Rata & - & $\mathbf{7 6 , 7 5}$ & - & - \\
\hline Prosentase & $\mathbf{1 0 0 \%}$ & - & $\mathbf{7 4 \%}$ & $\mathbf{2 6 \%}$ \\
\hline
\end{tabular}

Dari table 9, hasil belajar siswa menunjukkan rata-rata keefektifan siswa sebesar 76,75 siswa mencapai mencapai skor $\geq 75$. Prosentase ketuntasan 74\% dengan kategori modul efektif. Dengan demikian, dilihat dari segi keefektifan, dapat dikatakan bahwa Modul Komik Tematik Berbasis MI Kelas V SD efektif untuk digunakan dalam pembelajaran.

Uji coba lapangan dilaksanakan pada tanggal 16 Juli - 4 September 2018. Subjek uji coba lapangan sebanyak 250 siswa pada 7 Sekolah Dasar (SDN Sukun 1 Malang, SDN Bandungrejosari 3, SDN Lesanpuro 3, SDN Kedungkandang 1, SD Laboratorium UM, SDN Purwodadi 1, SDN Kesatrian 2). Peneliti melakukan uji coba lapangan untuk membelajarkan modul selama 3 hari dengan jadwal yang telah disesuaikan dengan sekolah. Guru dan peneliti membahas bahan yang akan diajarkan pada pertemuan pertama sesuai dengan RPP yang telah dirancang.

Pada pertemuan pertama, peneliti membelajarkan modul siswa bagian Sub tema 1 kepada siswa (sub tema lingkungan keluarga) peneliti membelajarkan modul sesuai dengan RPP pertemuan pertama. Peneliti melakukan apersepsi, informasi materi dan informasi 
tujuan. Setelah itu memperkenalkan modul kepada siswa. Siswa diminta untuk membaca judul dalam modul, kemudian menuliskan nama, nomer absen dan sekolah. Siswa diminta membaca bagian pendahuluan modul yanga berisi: kata pengantar, petunjuk penggunaan modul, bagian modul, peta konsep) dengan bimbingan guru. Setelah itu siswa diminta mempelajari sub tema 1. Siswa mengerjakan latihan, tugas yang terdapat dalam modul dengan semangat.

Pada pertemuan kedua, peneliti melaksanakan pembelajaran dengan modul sesuai dengan RPP yang telah disusun. Siswa diminta melanjutkan mengerjakan sub tema 2. Pada pertemuan ketiga, siswa mempelajari pembelajaran yang masih belum diselesaikan. Pada pertemuan terkahir, siswa hanya mengerjakan tes akhir modul yang terdapat dalam modul. Dari segi keefektifan, diperoleh rata-rata skor nilai keefektifan sebesar 76,75 siswa mencapai skor $\geq 75$. Prosentase ketuntasan modul $74 \%$ dengan kategori modul efektif.

\section{KESIMPULAN}

Data keefektifan diperoleh dari hasil belajar siswa dari tujuh sekolah (SDN Sukun 1 Malang, SDN Bandungrejosari 3, SDN Lesanpuro 3, SDN Kedungkandang 1, SD Laboraturium UM, SDN Purwodadi, SDN kesatrian 2) yang menunjukkan bahwa Modul Komik Tematik Berbasis MI Kelas V SD efektif untuk digunakan dalam pembelajaran.

\section{DAFTAR PUSTAKA}

Arikunto, S. 2012. Dasar-dasar evaluasi pendidikan (Edisi 2). Jakarta: Bumi Aksara.

Chatib, M. 2009. Sekolahnya Manusia Menjadikan Guru Kreatif. Bandung: PT. Mizan Pustaka.

Depdiknas. 2006. Pedoman Memilih dan Menyusun
Bahan Ajar. Jakarta:Departemen Pendidikan Nasional.

Gardner, Howard. 2003. Multiple Intelligences : The Theory in Practice A Reader.

Indaryati,dkk. 2015. Pengembangan Media Komik Pembelajaran Matematika Meningkatkan Motivasi dan Prestasi Belajar Kelas V. Jurnal Prima Edukasia. 3(1).

Onika, Dounglas et all. 2008. The effect of the multiple intelligence teaching strategy on the academic achievement of eight grade math students. Jurnal of Instructional. $35(2)$.

Trianto, 2010. Model pembelajaran tematik. . Prestasi pustaka. Surabaya.

Wahyuningsih , A. N. 2011. Pengembangan Media Komik Bergambar Materi Sistem Saraf Untuk Pembelajaran Yang Menggunakan Strategi PQ4R.. Jurnal PP. 1(2).

Yamasari,Y. 2010. Pengembangan Media Pembelajaran Matematika Berbasis ICT Yang Berkualitas. Makalah Yang Disajikan Dalam Seminar Nasional Pascasarjana X, ITS, Surabaya, 4 Agustus 2010. ((online) 